\title{
Pode a crise da COVID-19 acelerar a revisão da ordem global atual? A luta pela liderança do sistema internacional no séc. XXI ${ }^{1}$
}

https://doi.org/10.21814/uminho.ed.25.14

\section{Maria do Céu Pinto Arena}

Maria do Céu Pinto Arena (ORCID: 0000-0003-3083-3890) é Professora Associada com agregação do Departamento de Ciência Política da Escola de Economia e Gestão da Universidade do Minho. É investigadora do Centro de Investigação em Ciência Política (CICP) da mesma Universiade e especialista em assuntos das Nações Unidas, Mediterrâneo, Islão e Médio Oriente, sendo autora de várias dezenas de artigos e livros sobre estas temáticas.

\footnotetext{
1 Este estudo foi realizado no Centro de Pesquisa em Ciência Política (UID/CPO/00758/2020) da Universidade do Minho e apoiado pela Fundação Portuguesa de Ciência e Tecnologia (FCT) e pelo Ministério da Educação e Ciência através de fundos nacionais.
} 
Há um amplo consenso em redor da ideia de que o mundo está a passar por um processo de transição global de poder que deveria ser uma evolução a longo prazo, mas se tem revelado mais rápido e abrupto do que se previa. A riqueza e o poder estão-se a difundir-se para fora da Europa e dos Estados Unidos. O padrão geral de mudança intui-se desde há muito, embora não se conheça os contornos da ordem que a substituirá: em que medida a ordem liberal internacional, da forma como a conhecemos, vai continuar a existir? Que mudanças se vão operar na ordem internacional se ela persistir? E se a atual ordem acabar, que tipo de ordem vai substituí-la? As narrativas sobre a rutura e crise procuram dar respostas às grandes perguntas sobre a ordem no novo mundo multipolar, sobretudo, sobre o lugar ocupado pelas potências emergentes. Antes da chegada do coronavírus, o mundo acompanhava com interesse a disputa comercial e tecnológica entre as duas maiores economias: EUA e China. Agora, quando se fala no desenho de forças no cenário pós-coronavírus, a grande pergunta é se a China vai superar os Estados Unidos como líder global.

No entanto, "a ordem mundial liberal está a ser desafiada de maneiras fundamentais" (Duncombe e Dunne, 2018, p. 26), havendo "um amplo acordo de que o mundo está a testemunhar uma transição global de poder no longo prazo" (Ikenberry, 2018, p. 18). Nas Relaçôes Internacionais, a literatura que versa o fim ou a transição de poder na ordem internacional liberal parece ser concordante quanto ao facto de esta estar em derrocada. Afirmar que a ordem mundial liberal está em crise é apenas o ponto de partida para esta indagação. É necessário fazer uma análise mais fina para mostrar se, quais e como é que os elementos dessa ordem estão em mudança ou em colapso.

Segundo Amitav Acharya (2017, p. 272), a crise da ordem liberal tem raízes profundas e esta deve-se a mudanças estruturais e de longa duração a nível da economia e da política internacional. John J. Mearsheimer (2019) afirma que a ordem estava destinada ao fracasso desde o início, pois esta continha em si as sementes da sua própria destruição. Além da ordem internacional, as ordens regionais em várias partes do mundo também estão em transição ou colapso (Ikenberry, 2018, p. 17).

As razóes para o declínio da ordem internacional liberal podem ser encontradas a vários níveis: seja na própria estrutura interna, quanto externamente, por meio de outros atores e processos exteriores à área hegemónica ocidental. Segundo Constance 
Duncombe e Tim Dunne, uma ordem internacional corresponde a uma determinada configuração (com elementos materiais e normativos), que se cristalizam num determinado período histórico, dando origem a uma ordem específica. Trata-se de uma conceção baseada na noção de "embedded liberalism”, de John G. Ruggie (1983), o qual defende que a ordem internacional que emergiu no pós-II Guerra tem um substrato liberal ligado à ordem económica internacional que emergiu. Ela foi fruto do consenso entre os principais vencedores da Guerra, com particular ênfase para os Estados Unidos da América e a Inglaterra (Ruggie, 1982). Na base dessa ordem, há uma confluência entre a estrutura material de poder (as instituiçôes propriamente ditas, como a ONU ou as “instituições de Bretton Woods”) e um “propósito social legítimo" (Ruggie, 1982, p. 380 e Duncombe e Dunne, 2018, p. 26).

Numa visão realista, uma ordem é um grupo organizado de instituições internacionais que ajudam a gerir as interaçôes entre os Estados (ou a lidar com os Estados não-membros). São as grandes potências que criam e gerem as ordens. As ordens internacionais são compostas por instituições que podem ter uma abrangência regional ou global. As instituições internacionais ${ }^{2}$ são regras estabelecidas pelas grandes potências e que as mesmas se comprometem a seguir, mas de que são as grandes beneficiárias ${ }^{3}$.

Ainda no que diz respeito às ordens internacionais, é necessário distinguir as "bounded orders" das ordens internacionais propriamente ditas. As "bounded orders" têm um número limitado de membros e, na maior parte dos casos, são dominadas por uma grande potência. Estas são desenhadas para permitir que essas potências possam gerir a competição de segurança entre si. $\mathrm{O}$ exemplo mais acabado deste tipo foi a ordem bipolar vigente durante a Guerra Fria. Mearsheimer afirma que essa ordem bipolar coexistiu com uma ordem internacional liberal, que consistiu numa matriz frouxa e

\footnotetext{
2 Segundo Dunne e Flockhart, há a tendência para confundir o futuro da ordem internacional liberal com a questão do declínio na hegemonia dos EUA. São duas questões ligadas, mas distintas. O liberalismo implica a agência de muitos atores. A ordenação liberal da ordem pode ser mais resistente e duradoura, ao contrário da hegemonia dos EUA (Dunne \& Flockhart, 2011).

3 Podem ser compostas por diferentes tipos de instituições, por exemplo instituiçóes económicas, como o Banco Mundial e o Fundo Monetário Internacional; de segurança, como a Organização do Tratado do Atlântico Norte (NATO) ou outras instituições, como a Organização das Nações Unidas (ONU), a Organização Mundial de Saúde (OMS), ou outras.
} 
pouco robusta de organizações multilaterais. Nesta, os EUA forneciam bens públicos globais através das organizaçóes de Bretton Woods ou da NATO. Estas serviram para ajudar a reconstruir a Europa, reforçar a ordem internacional, mas também para permitir conter a URSS.

Acharya considera que esta ordem tinha como alicerces o comércio livre, as instituições multilaterais, o reforço da democracia e dos valores liberais (Acharya, 2017, p. 272). Os regimes e instituiçôes reguladoras estabeleceram padróes de governança em quase todos os domínios da política mundial: meio ambiente, comércio, transporte marítimo, aviação, internet, armas de destruição maciça, armamento convencional, direitos humanos, entre outros. Essa rede de regimes foi projetada para ancorar os Estados e outros atores influentes à ordem mundial liberal (Ducombe e Dunne, 2018). Os EUA, enquanto Estado dominante, têm uma enorme influência nos regimes internacionais e no seio das instituiçôes que compóem a ordem internacional liberal. $\mathrm{O}$ autor afirma que a liderança da ordem hegemónica global liderada pelos EUA, não foi, na realidade, tão forte e extensa quanto geralmente se supõe (Acharya, 2017, p. 271). Uma das razões é porque esta ordem abarcou pouco mais além dos Estados e regióes mais desenvolvidos do mundo - nomeadamente, os EUA, o Reino Unido, a Europa Ocidental e a Austrália ${ }^{4}$. Em segundo lugar, os efeitos da ordem liberal, de que as democracias liberais ocidentais eram o arquétipo e encarnação, não se disseminaram de igual forma para os Estados em desenvolvimento, fazendo destes beneficiários (e não apenas objetos passivos) dos princípios liberais. Por último, e tendo em conta este raciocínio, o autor argumenta que a ordem deveria ser vista como uma ordem internacional limitada e não como uma ordem global inclusiva (Acharya, 2017, p. 271).

Mearsheimer afirma que a queda do muro de Berlim, em 1989 e o fim da União Soviética, em 1991, possibilitaram o início de uma Nova Ordem Mundial, a qual nasceu fadada ao fracasso. De acordo com Mearsheimer, essa assumiu um caráter unipolar. O “momento unipolar" dos EUA (Krauthammer, 1990/91) resultou numa ordem internacional liberal, em que os EUA prosseguiram os seguintes objetivos: aumentar a filiação nas instituiçôes e criar outras novas (institucionalismo); criar uma economia

4 Também Nye, 2017: 12. 
internacional aberta e inclusiva (interdependência económica); difundir e espalhar a democracia liberal, nomeadamente na região do Médio Oriente ("paz democrática") (Doyle, 1995).

Mearsheimer defende que esta ordem internacional liberal está a chegar ao seu fim. As causas dessa decadência são tanto internas, quanto externas. São elas: os fracassos das políticas de intervenção para a promoção da democracia da administração Bush; os problemas relacionados com a soberania e identidade nacionais; os efeitos e custos da hiperglobalização; a ascensão de China e Rússia. A pretensão norte-americana de exportar a sua visão liberal, fomentando, teoricamente, a paz e a liberdade mundial, foi desautorizada pela atuação política de Washington, sobretudo após o 11 de setembro de 2001. A guerra contra o Afeganistão e a intervenção militar contra o Iraque foram alguns destes exemplos. Nestes casos, os efeitos negativos das intervenções militares dos EUA minaram o apoio do eleitorado americano a um papel interventivo global (Nye, 2016, p. 15).

Relativamente às responsabilidades que a liderança da ordem liberal acarreta, é de notar que a promoção dos valores liberais, como a promoção da democracia, é um processo complexo e ambíguo, que legitima o seu propósito nos valores da própria ideologia que tenta exportar. Desta forma, as invasóes e ocupações motivadas por este propósito, geram revolta nas populações dos territórios que delas são alvo, aumentando os custos das intervençóes, ao mesmo tempo que diminuem as suas probabilidades de sucesso. Estas afetam drasticamente o apoio da opinião pública à prossecução de um papel global interventivo por parte das potências liberais (Nye, 2017, p. 15). Efetivamente, são estes sentimentos que potenciam o desenvolvimento de anticorpos contra a ordem liberal, seja nos países ocidentais, seja, sobretudo, no "Global South"s. É neste sentido que Nye considera que a ascensão dos populismos, principalmente nos EUA e na Europa, marca o início do fim da era contemporânea de globalização (Nye, 2017, p. 14-15).

5 O "Sul Global” é um termo que engloba os países mais pobres ou os países em vias de desenvolvimento. Refere-se geralmente aos países que têm um passado de colonialismo, neocolonialismo e uma estrutura social e económica marcada por grandes desigualdades. 
Relativamente aos fatores internos, pode-se referir a crise económica e financeira, principalmente a de 2008, enfraqueceu as instituições da ordem internacional de maneira dramática. No campo político, podemos identificar a ascensão, nos países ocidentais, de lideranças políticas populistas que são eleitas com base em programas eleitorais críticos dos mecanismos e processos próprios da ordem liberal, nomeadamente das instituiçốes multilaterais, ou das fronteiras e dos mercados abertos.

Segundo Mearsheimer a hiperglobalização teve efeitos particularmente nefastos nas democracias liberais, afetando, em particular, as classes baixa e média, agudizando as desigualdades económicas e agravando os níveis de insatisfação generalizada. A estes problemas, vieram somar-se as reações nacionalistas provocadas pelas migrações e o sentido de perda de soberania nas democracias liberais. Os ressentimentos nacionalistas tiveram consequências diretas nas democracias ocidentais, conduzindo a um inesperado voto favorável ao Brexit e causando divisões políticas nos EUA. Esse senso de aspiraçôes traídas pela globalização, ajudaram Donald Trump a vencer as eleições e alimentaram o apoio aos líderes nacionalistas e populistas em todo o mundo (Mearsheimer, 2019).

Do lado dos fatores externos, destaca-se a ascensão da China como principal fator de trasmutação do quadro de poder internacional. Distingue-se também o fortalecimento da Rússia, que mesmo não possuindo uma economia bastante forte para rivalizar com a China e EUA, é um ator militar relevante, possuindo um enorme território rico em recursos e ocupando uma posição geográfica estratégica. A administração Obama tentou integrar os países emergentes na liderança global em troca do cumprimento de regras e normas internacionais. Apesar destes esforços, a crise financeira de 2008 veio fragilizar a ordem liberal, criando oportunidades para a China se afirmar (Ikenberry, 2018, p. 17-18).

A transição do poder mundial é algo inegável - "the 'rest' are gaining ground on the 'West"' (Ikenberry, 2018, p. 18) -, o que vai alterar significativamente a balança de poder. Em relação às consequências desta alteração, as opiniốes são algo divergentes. A visão clássica, defendida pelos realistas, afirma que quando o Estado hegemónico perde a sua influência, outro Estado emergirá para ocupar o seu lugar, com base num ciclo de alternância. Esta visão é baseada na experiência histórica europeia e ocidental (Carr, 
1964; Gilpin, 1981 e Kennedy, 1987). Outros argumentam autores que os EUA ainda detêm influência e capacidade de exercer uma liderança hegemónica e que a teoria da transição pode estar errada.

Existe na atualidade uma difusão de poder orientada, não só para os Estados, mas também para os atores não estatais. A complexidade está a crescer num mundo em que a política mundial não será uma arena exclusiva dos Estados. O enfraquecimento do sistema unipolar deve-se à difusão do poder para atores não-estatais. A política internacional tem sido caracterizada pelo acelerado desenvolvimento de uma governação global transnacional, onde as organizações privadas, ONG, movimentos terroristas, multinacionais e os indivíduos, desempenham um papel cada vez mais importante na definição da mesma. Assim, os Estados continuarão a possuir poder e recursos, mas a arena da política internacional será certamente mais dinâmica, de forma que estes terão menos capacidade de controlar e orientar o sistema.

\section{UMA CRISE DE AUTORIDADE}

O sucesso da ordem internacional em estabilizar e proteger o mundo nas últimas sete décadas levou á criação de um consenso sólido de que defender, consolidar e estender esse sistema, é a tarefa central da política externa norte americana. No entanto, esta realidade tem vindo a ser posta em causa de uma forma que não tem precedentes desde a II Guerra. Com a eleição de Donald Trump, os sentimentos nacionalistas e protecionistas dos EUA, têm vindo a crescer pois, o atual presidente acredita que os custos de manter a ordem global são maiores do que os seus benefícios. A agenda dos valores liberais sofreu um forte abalo com a eleição de Trump, acompanhada de uma erosão do soft power americano no contexto internacional.

A ordem está a ser desafiada através de uma crise de autoridade. Este problema interno centra-se no facto dos EUA, enquanto ator responsável pelo desenvolvimento da ordem internacional, estarem a afastar-se dos seus projetos de promoção dos valores liberais, pondo em questão a sua liderança da ordem internacional (Duncombe e Dunne, 2018, p. 27). Segundo Acharya: "a vitória de Trump e o Brexit sugerem que o atual desafio à ordem liberal é tanto, se não mais, de dentro como de fora. A ascensão 
de Trump ao poder é uma consequência - não uma causa - do declínio da ordem liberal, especialmente do fracasso em abordar as preocupaçóes dos eleitores, abandonados pela mudança de poder global” (Acharya, 2017, p. 272).

Segundo os autores, a ordem liberal atual está na reta final, desafiada devido a uma crise de autoridade nos países ocidentais e à ascensão do "resto". Ikenberry foca-se nesta crise, isto é, na falta de apego dos EUA aos valores liberais, demonstrada pela própria eleição de Trump, que veio colocar a ordem internacional liberal ainda mais em risco. $\mathrm{O}$ abandono de acordos e compromissos internacionais sinalizam a retração norte-americana do multilateralismo e talvez mais do que isso: uma vontade de contribuir para o seu desmantelamento. Com Trump, os EUA retiraram-se do Acordo de Paris sobre as alteraçốes climáticas, da UNESCO, do Conselho de Direitos Humanos da ONU, da Parceria Transpacífico (que deveria, aliás, servir de contraponto à "Belt \& Road" chinesa), do acordo nuclear multilateral com o Irão, do Tratado sobre Forças Nucleares de Alcance Intermediário, do Tratado de Céus Abertos. Em abril, Trump anunciou também a suspensão temporária de sua contribuição financeira à Organização Mundial de Saúde e, em maio, confirmou a saída de Washington. O presidente americano acusou a OMS de não ter independência em relação à China, tendo sido conivente na ocultação de informação relevante sobre a propagação do novo coronavírus, o que aumentou os riscos da crise sanitária global.

Além disso, o protecionismo comercial americano, a política de "America First" e a consequente retirada dos EUA da liderança comercial multilateral, cria um espaço que outros países já estão a ocupar, a começar pela China. Outras potências, como o Japão e a Índia apostam na abertura comercial para modernizar as suas economias. O protecionismo comercial destrói o sistema comercial multilateral e prenuncia negociações baseadas na força, no "Realpolitik” e peso de cada país. O risco de eclodirem guerras comerciais, que parecia afastado há muito, emerge com mais força do que nunca.

\section{UMA ORDEM GLOBAL RADICALMENTE DIFERENTE?}

Mearsheimer salienta que existirão no futuro três ordens realistas diferentes: uma ordem internacional geral mais "fina"; duas ordens mais "densas" e limitadas: 
uma liderada pela China e outra pelos EUA. Ikenberry (2018) defende a continuidade da ordem liberal, mesmo com as mudanças na balança de poder em curso. $\mathrm{O}$ autor utiliza as Teorias da Transição de poder como base para a sua análise, oferecendo uma perspectiva evolutiva da transição e sublinhando os aspectos relacionados com a continuidade da ordem internacional liberal moderna. Ikenberry argumenta que, apesar de terem sido os EUA a dar forma ao sistema liberal, as características mais abrangentes deste sistema foram, na realidade, o resultado de séculos de luta pelos princípios e instituições que o caraterizam (Ikenberry, 2018, p. 22) que perdurarão, sobrevivendo aos seus fundadores.

Mesmo que o poder hegemónico do EUA esteja em declínio, os elementos característicos da ordem, como a sua abertura, as suas regras e a cooperação multilateral, tendem a persistir, pois estão enraizados no sistema internacional. Além disso, a ordem internacional é complexa, multinível e multifacetada, não dependendo, enquanto forma política, do Estado hegemónico: a ordem desenvolveu os seus próprios processos, pelo que já não é tão dependente do “hegemon". Além disso, a complexidade inerente à ordem liberal vigente, leva o autor a afirmar que a ordem internacional contemporânea é bastante mais forte do que a anterior, de forma que as mudanças que a venham a afetar, não dependerão exclusivamente da manutenção da posição hegemónica dos EUA, mas pautar-se-ão pela continuidade, evolução, adaptação e negociação (Ikenberry, 2018, p. 21).

Nye (2017) segue um raciocínio semelhante explorando o histórico do papel dos EUA na construção da ordem atual. Ora, esta ordem baseia-se em dois projetos internacionalistas de longo prazo: os princípios de Vestefália e o internacionalismo liberal. ${ }^{6}$ Ikenberry defende que, se a ordem resistir, será devido a estes dois projetos e ao seu sucesso. $\mathrm{O}$ autor explica que são quatro as caraterísticas que reforçam e atraem os Estados para a ordem atual: a integração; as oportunidades de liderança e de autoridade partilhada; os ganhos económicos da participação e a diversidade de modelos e

\footnotetext{
6 Os princípios de Vestefália são a soberania, a integridade territorial e a política de não-intervenção. Estes princípios foram adotados em todo o planeta, impulsionando, inclusivamente, a descolonização e o processo da independência dos povos não autónomos. Além disso, intensificou o projeto internacional liberal, um sistema baseado em regras estabelecidas pelo Ocidente.
} 
estratégias de crescimento e desenvolvimento (Ikenberry, 2018, p. 25). Estas características criam incentivos e oportunidades para que os Estados integrem a ordem, ao mesmo tempo que dificultam a decisão daqueles que a querem abandonar.

Segundo Acharya, mesmo que as potências emergentes se posicionem de forma desafiadora em relação ao Ocidente, exigindo maior participação e um sistema internacional mais justo e igualitário, continuam a agir de forma a garantir que alguns aspectos da ordem liberal continuem a existir. Para aquele autor, o mundo não será multipolar, mas um sistema onde vigora a multiplicidade. A nova ordem não será radicalmente diferente, pois existem diferenças entre o contexto atual e o período pré-II Guerra Mundial onde essa ordem originou: (1) no período da II Guerra, havia grandes potências (Japão, EUA, URSS e potências europeias); no mundo de hoje existem potências estatais e não estatais; (2) a natureza da interdependência económica é mais densa e mais global do que no período que antecedeu o segundo conflito mundial; (3) hoje existe uma densidade muito maior de instituições internacionais duráveis e de instituições regionais; (4) os desafios à ordem e estabilidade da mesma tornaram-se mais complexos. Antes o grande desafio eram os conflitos entre Estados, hoje os desafios à segurança são diversificados e não exclusivamente militares (Acharya, 2017, p. 276-277).

No que respeita à transição, os autores divergem na sua apreciação da futura ordem. Para Acharya, a ordem internacional que vai emergir consistirá num mundo multiplex, não num mundo multipolar (Acharya, 2017, p. 277). Acharya descreve um mundo multiplex como uma ordem em que elementos da ordem liberal sobreviverão, mas estarão embutidos num complexo de múltiplas ordens internacionais transversais (Acharya, 2017, p. 272). A sua complexidade deve-se ao facto da política mundial não ser uma arena exclusiva dos Estados. A ordem multiplex é diferente de um contexto multipolar, devido às dinâmicas únicas que se operam na atualidade, como a densa interdependência económica, a multiplicidade de instituiçốes internacionais e os novos desafios securitários (Nye, 2017; Acharya, 2017).

A futura ordem será, então, caracterizada por uma forte globalização, motivada por preocupações de desenvolvimento e não por motivações exclusivamente comerciais. Esta ordem poderá ser liderada pelo Oriente e não pelo Ocidente (Acharya, 2017, p. 278). Acharya defende que a cooperação internacional será necessária, 
principalmente associada a problemáticas específicas e não a ideologias. Será necessário reconhecer a importância das potências regionais e do regionalismo, pois estas contribuirão de forma positiva para a cooperação global. A cooperação multilateral será uma necessidade imprescindível a qualquer ordem. Quanto à ordem liberal, esta será apenas uma das ordens da nova ordem multiplex, coexistindo com outras. Enquanto a governança global se irá manter, a arquitetura da ordem liberal continuará a fragmentar-se e a descentralizar-se.

Duncombe e Dunne são menos afirmativos na sua avaliação de quais os aspetos da ordem liberal que estão em risco, de como as suas dinâmicas serão alteradas e se o sistema será capaz de se adaptar e sobreviver. No entanto, tal como Ikenberry, estes autores também afirmam que a nova ordem não será apenas menos americana, como também, menos liberal (2018, p. 28). Acreditam que os EUA não desaparecerão totalmente do cenário internacional, conseguindo manter uma posição de relevância através do seu soft power (2018, p. 33), tal como Keohane alvitrou em meados dos anos 80, ou através do "poder estrutural” de Susan Strange (1987 e 1988) que sustenta a ordem liderada pelos EUA: alianças de segurança a nível global, relações de mercado, solidariedade democrática liberal e alinhamentos geopolíticos profundamente enraizados. Para Acharya, a multiplicidade no sistema internacional, não é sinónimo de que os EUA estão em declínio - simplesmente que não estão em posição de impor as normas e dominar o sistema (Acharya, 2017, p. 277).

A nova ordem vai ser diferente da atual (Nye, 2017). Esta será caraterizada pela ascensão das potências emergentes; a diminuição da capacidade decisória americana; a difusão do poder para atores não estatais; novas preocupações e desafios; a diminuição da capacidade dos governos de tomar decisóes e o aumento da complexidade da política e relações internacionais.

Ikenberry assinala que a manutenção da ordem internacional não depende do respaldo do poder americano. Ikenberry concorda com Nye relativamente à transição de poder, mas afirma que a ordem atual dificilmente soçobrará, visto que os Estados emergentes não são revisionistas: pretendem, sim, um maior acesso e mais poder em 
relação aos cargos e posições de liderança internacional (Ikenberry, 2018, p. 22) ${ }^{7}$. Esta crença assenta no facto de existirem ainda muitas fontes de poder hegemónico norteamericano e outros elementos de continuidade em relação ao sistema atual (Ikenberry, 2018, p. 19-20), tal como antecipado por Keohane e Strange. Nye acredita que, apesar de ter as condições ter uma posição de liderança, a China não ultrapassará, nas próximas décadas, os EUA enquanto ator dominante da política internacional (Nye, 2017, p. 13).

Quanto aos Estados emergentes, a China beneficia de forma significativa da ordem liberal atual e, por isso, não promoverá a eliminação da mesma, desejando apenas aumentar a sua capacidade de decisão e influência dentro desta. Embora os Estados emergentes não-ocidentais não queiram que seja o Ocidente a dominar as instituições globais, estão interessados na preservação das suas regras e princípios organizacionais de que tanto têm beneficiado, nomeadamente a economia mundial aberta e o multilateralismo. Segundo Miles Kahler (2016), as potências emergentes como a China, o Brasil e a Índia, têm demonstrado ser "globalizadores conservadores” (Kahler, 2016).

A literatura tende a concordar que as potências emergentes beneficiam de alguns dos aspetos da ordem liberal e que, por isso, irão desempenhar um importante papel no processo de transformação da presente ordem. Nye, por exemplo, argumenta que a China não pretende a eliminação total da ordem liberal, mas sim a transformação desta, de forma a garantir uma posição de liderança e de influência (Nye, 2017, p. 12-13). De recordar, que a adesão de Pequim à Organização Mundial do Comércio, em 2001, escancarou-lhe as portas do comércio mundial e permitiu a sua consolidação enquanto potência global (Friedman, 2020). Se a crise mundial desencadeada pela COVID-19, provocar uma travagem da globalização ou uma "desglobalização" parcial, a economia chinesa ficará particularmente exposta, pois é muito mais dependente das exportaçóes do que a americana ou a europeia (Fernandes, 2020). Duncombe e Dunne

\footnotetext{
7 No Fundo Monetário Internacional, os seis Estados que, até 2016, possuíam quotas de capital mais elevadas eram os EUA, Reino Unido, Alemanha, França e Japão. Estes países detinham mais de 40\% dos votos. Em 2010, o G-20 decidiu transferir pelo menos 5\% dos direitos de voto para países emergentes como o Brasil, China, Índia e Rússia. Esta reforma entrou em vigor só em janeiro de 2016. A quota da China supera agora países como a Alemanha, França, Reino Unido e Itália com o aumento de 3,65\% para 6,09\% (3o lugar). Beijing tem agora um cargo importante, contando com um Deputy Managing Director.
} 
dizem existir boas razões para acreditar que a ascensão das novas potências face às democracias liberais irá fornecer à ordem liberal os bens públicos que esta necessita, uma vez que estas novas potências acreditam que a ordem liberal "is the worst form of global governance-except for all the others" (Duncombe e Dunne, 2018, p. 42). Apesar de estes Estados não se afirmarem como defensores convictos desta ordem, reconhecem que é a melhor entre todas as opçóes. O apoio à ordem liberal acontecerá, segundo o autor, a curto prazo, por incapacidade de mudar as regras do jogo ou dependência das opções existentes (Acharya, 2017, p. 275-276). Estados como a China, ou os BRICS, em geral, querem preservar o sistema internacional orientado por regras, com princípios organizacionais, uma economia mundial aberta e o acesso justo e igualitário ao sistema global (Ikenberry, 2018, p. 25-26).

Mesmo partindo do princípio que a China queira minar e alterar a ordem internacional liberal, os constrangimentos que iria ter de enfrentar seriam intimidadores: teria de erigir novas regras e instituiçóes que refletissem um modelo alternativo viável de organização política e económica. Em rigor, a estratégia mercantilista da China funciona melhor num mundo aberto e liberal. Além disso, tal pressupóe que os outros Estados do sistema aceitariam a sua liderança, o que só aconteceria se os mesmos tivessem algo a ganhar. São essas dificuldades e a inserção das potências emergentes na ordem atual, que tornam, para Ikenberry, um cenário de alteração do sistema pouco provável. O autor acha mais provável que as potências emergentes se tornem defensores do internacionalismo liberal e que os elementos básicos da ordem durem para além do declínio da hegemonia americana.

Nye afirma que o crescimento de certas potências (Brasil, China e Índia) é evidente. Contudo, nenhuma delas está pronta para fazer "tirar" o ceptro aos EUA (Nye, 2017, p. 16).

\section{A ASCENSÃO DO REST}

Será que as potências emergentes querem integrar e desenvolver a ordem internacional já existente ou querem transformá-la? Podem ser consideradas simples stakebolders ou potências revisionistas? Alguns observadores consideram a ascensão da 
China como a principal ameaça à ordem internacional uma vez que esta parece não compartilhar a ideia que o poder implica assumir responsabilidades igualmente grandes e que, quando esta ultrapassar os EUA, não será capaz de apoiar a ordem atual.

Alguns BRICS (Brasil, Rússia, Índia, China e África do Sul) não estão em posição de explorar e, de certa forma, transformar a ordem internacional como ambicionam, pois, três deles (Brasil, Rússia e África do Sul), estão a passar por dificuldades económicas e problemas políticos, internos ou na frente internacional. A Rússia tem recuperado algum do seu poder, mas não tem beneficiado da globalização podendo, consequentemente, ter um menor interesse na preservação da ordem liberal (Acharya, 2017, p. 275).

Para os realistas, a China tentará, em primeiro lugar, dominar as regióes adjacentes e as suas "esferas de influência", como já acontece nas suas zonas adjacentes, como o Mar do sul da China (Duncombe e Dunne, p. 27-28; Walt, 2011, p. 9) e a fronteira com a Índia (Mearsheimer, 2020). Walt diz que, à semelhança do que aconteceu com os EUA, os interesses vitais da China crescerão paralelamente ao avolumar do seu poder. O reforço do poder militar advirá da necessidade de proteger as "esferas de influência" sempre mais alargadas. No caso da Rússia, destaca-se a o seu protagonismo na guerra civil da Síria, o desafio à presença ocidental na Europa de leste, que resultou na invasão da Ucrânia e na anexação da Crimeia, e a necessidade de fazer frente à presença da NATO na sua vizinhança próxima. O crescimento económico da China e da Índia também veio permitir o crescimento do seu protagonismo na arena internacional. (Duncombe \& Dunne, 2018, p. 28).

No caso do relacionamento entre estes dois países, há que sublinhar que as velhas rivalidades e conflitos existentes entre Pequim e Nova Delhi, não permitem uma visão compartilhada da ordem internacional (Acharya, 2018, p. 275-276). Há a salientar o recente incidente entre os exércitos indiano e chinês nas áreas fronteiriças disputadas dos Himalaias que resultaram em várias dezenas de mortos e demonstram a afirmação do poder chinês nas suas áreas fronteiriças, com a maior frequência de incursões em áreas geralmente aceitas como estando sob controle indiano (Sitaraman, 2020). No entanto, é curioso reparar que a Índia é um país chave do Asian Infrastructure Investiment Bank 
(AIIB - Banco Asiático de Investimento em Infraestrutura) $)^{8}$. A importância deste banco, de que Beijing é o maior acionista (com 50\% do capital) assenta no facto de ser visto como um challenger do Banco Mundial e do Banco Asiático de Desenvolvimento, ambos credores multilaterais que contam com Washington e os seus aliados como os seus maiores financiadores. As numerosas adesóes, inclusive por parte de países da UE e outros aliados de Washington, são interpretadas como um sinal da crescente influência internacional da China à custa dos EUA. Contudo, a Índia é contra a iniciativa chinesa "Belt \& Road".

É de referir que enquanto as atenções do mundo estavam centradas na disseminação do vírus, o Parlamento chinês aprovou quase por unanimidade a polémica lei sobre segurança nacional para Hong Kong, minando a autonomia do território e esvaziando, na prática, o estatuto de autonomia e o princípio "um país, dois sistemas" negociado com o Reino Unido em 1997. Mudou também a linguagem sobre Taiwan, o que pode indiciar o avolumar das pressões para a reunificação do território. O Governo chinês reafirmou que se oporá a "qualquer atividade separatista que busque a independência de Taiwan", e omitiu a palavra "pacífica”, habitualmente empregue como uma condição para a integração de Taiwan na China (Gomes 2020; Cabral, 2020).

A China reúne condições económicas, financeiras, geopolíticas, culturais, tecnológicas e militares quase sem precedentes Pequim não está ainda à altura de ultrapassar os EUA no pódio por duas razões: não tem um poder militar tão forte, o que é um requisito fulcral para um aspirante a superpotência; internamente, a China apresenta grandes discrepâncias entre o interior e o litoral, o que é um fator de debilidade.

A iniciativa chinesa Belt and Road (B\&R) é um claro sinal da hegemonia e da expansão chinesa através do globo. A Nova Rota da Seda é um megaprojeto chinês de investimento em infraestruturas de transporte para modernizar as ligações entre a China e a Europa por via terrestre e marítima. Constitui uma prioridade da política

8 A importância deste banco assenta no financiamento de projetos massivos de desenvolvimento sustentável no continente asiático. O capital do novo banco é enorme e pode vir a financiar mais projetos asiáticos do que o FMI. A iniciativa foi boicotada por alguns países, mas já conta com 82 Estados-membros e outros 20 interessados em aderir. 
externa chinesa, através da qual bancos chineses estão a conceder empréstimos para a construção e modernização de portos, aeroportos, autoestradas, linhas ferroviárias e parques industriais ao longo de toda a massa continental eurasiática. A China adquiriu o monopólio sobre o porto de Pireu na Grécia e participações em outros 12 portos, incluindo na Espanha, França, Bélgica e Holanda (Kakissis, 2018). Portugal apoia formalmente o projeto $B \& R$ e quer integrar Sines como porto de ligação entre as rotas do extremo oriente e as rotas atlânticas para as Américas.

O investimento chinês não é um simples investimento financeiro, mas sim de influência. Treze países europeus já se associaram à Nova Rota da Seda, nomeadamente na Europa de leste, atraídos pela perspetiva de modernização de infraestruturas e criação de emprego. A falta de investimento e liquidez, agravadas pelas políticas de austeridade da UE, tornaram o investimento chinês altamente apetecível. Após a crise financeira de 2008-2009, os fundos e empresas estatais chinesas decidiram abrir a carteira e fazer aquisiçôes em várias partes da Europa. Após de ter inserido como ator preponderante nas cadeias de valor logístico e produção industrial, a China quer deixar de ser "fábrica do mundo" e tornar-se gigante da inovação. Se a China continuar a adquirir portos e empresas em áreas chave, como fez em Portugal $^{9}$, isso será o prelúdio de uma maior influência política, condicionando a economia destes países e as suas políticas internas e externas (Behravesh, 2020) ${ }^{10}$. A partir de 2017, a UE despertou finalmente para a

9 É o caso da EDP, da empresa gestora das redes energéticas nacionais - REN, da Fidelidade e Multicare, do grupo Espírito Santo Saúde ou do Millenium BCP.

10 Ver o caso recente do Irão: quando o problema do coronavírus foi oficialmente detetado em janeiro, fazendo um número assustador de vítimas, as autoridades iranianas não fizeram nada para pôr fim às viagens entre os dois países, numa aparente tentativa de não afetar os laços diplomáticos. Apesar do governo ter decidido, a 31 de janeiro suspender todos os voos entre o Irão e a China, algumas companhias aéreas iranianas, não só não interromperam os voos, como também ajudaram a transferir passageiros com destino à China para outros países. Ver ainda o caso da Grécia: em junho de 2017, a Grécia bloqueou uma declaração da UE nas Naçôes Unidas criticando a situação de direitos humanos na China. A Grécia e a Hungria bloquearam uma declaração que se referia explicitamente à China, exortando-a a respeitar a decisão do Tribunal Permanente de Arbitragem sobre a disputa no Mar do sul da China. A declaração acabou por ser aprovada em termos genéricos e sem nomear a China diretamente. A estratégia teve êxito novamente em março de 2018, quando todos os Estados-membros da UE tiveram, no Conselho de Direitos Humanos das Nações Unidas, de se abster de uma resolução apresentada pela China que subverteu a defesa dos direitos humanos, privilegiando o papel do Estado soberano, em detrimento de uma conceção individual dos mesmos, e concentrando-se em mecanismos de diálogo e cooperação intergovernamental, a fim de impedir o exame da comunidade internacional (Piccone. 2018; Mitchell, 2018; Kothari, 2018). 
necessidade de escrutinar o investimento de países terceiros em setores estratégicos dos Estados-membros, protegendo os interesses europeus de potenciais ameaças ocultas nos investimentos de países terceiros, nos quais a China se inclui. A UE procurou blindar-se contra potenciais riscos para a segurança interna e ordem pública no bloco comunitário. Para salvaguardar os interesses europeus, a UE decidiu em 2019, coordenar a análise dos investimentos provenientes de países terceiros a fim de verificar se estes ameaçam ou não a segurança ou a ordem pública (European Commission, 2019). Recentemente, a vice-presidente da Comissão Europeia, Margrethe Vestager, afirmou que a crise causada pela pandemia torna as empresas europeias vulneráveis a investidas de países terceiros. Vestager considera que os Estados-membros devem entrar no capital de empresas afetadas pela pandemia, se necessário, para impedir que os chineses comprem posições e passem a controlar setores essenciais, tal como aconteceu na última crise, inclusive em Portugal (Crisóstomos, 2020).

\section{A PANDEMIA DA COVID-19: A CHINA CONTRA-ATACA}

A crise causada pelo vírus SARS-CoV-2 está a acelerar tendências geopolíticas que se desenhavam antes do coronavírus, como o facto de Washington se estar a afastar a passos largos da liderança global. Os Estados Unidos estão mais centrados nas prioridades internas e menos dispostos a liderar uma resposta internacional à pandemia, $\mathrm{o}$ que abriu espaço para o avanço de Pequim. Em rigor, a chegada à Casa Branca de Donald Trump deu a Pequim a oportunidade de se posicionar como baluarte da ordem mundial. Mearsheimer, o famoso cientista político e teórico das relações internacionais da Universidade de Chicago, afirmou que foram os EUA, que, ao longo dos anos $90 \mathrm{e}$ da primeira década e meia do séc. XXI, "insensatamente” (“foolishly”) envidaram esforços para tornar a China uma potência económica (Mearsheimer, 2020).

A crise financeira de 2008-2009 permitiu à China adquirir protagonismo na economia mundial, abrindo-lhe as portas para a sua política de aquisiçóes e investimentos de empresas de alto valor e de infraestruturas com importância geopolítica. Contudo, foi a política da administração Trump de "America First" que reforçou essa tendência. Pode-se afirmar que a China já estava bem posicionada na corrida, mas que os EUA, que levavam a dianteira, deixaram-se ficar para trás, dando o lugar à China. É irónico 
que, enquanto os fundadores da ordem liberal estão a recuar (pelo menos temporariamente), e a própria ordem está-se a esboroar, a China passou a oferecer apoio, ainda que qualificado, a essa ordem. O presidente Xi Jinping pôs em campo a sua estratégia de relações públicas no seu discurso em Davos, pouco dias antes da tomada de posse de Trump. No primeiro Fórum Económico Mundial de Davos depois do "Brexit" e das eleições dos EUA, os defensores da globalização encontraram em Xi Jinping o seu novo paladino na defesa dos ideais da globalização e o do comércio livre (Aníbal, 2017). O líder chinês lançou-se uma defesa entusiasta da globalização económica, do livre comércio e da luta contra as alteraçôes climáticas. O primeiro-ministro chinês, $\mathrm{Li}$ Keqiang também defendeu, num artigo na imprensa internacional que a China "oferece uma âncora de estabilidade e crescimento com a sua mensagem consistente de apoio às reformas, abertura e livre comércio... A China mantém-se firme com a Organização Mundial do Comércio e acordos multilaterais de livre comércio projetados para serem inclusivos" (Li Keqiang, 2017).

Durante o seu mandato, Xi Jinping tornou-se um dos líderes chineses que mais viajou na história recente do país. $\mathrm{Na} \mathrm{ONU}$, a China também aumentou o seu soft power através do reforço do seu contributo para as operaçôes de paz. Nos últimos trinta anos, o envolvimento da China na manutenção da paz aumentou dramaticamente. A China fornece agora o décimo maior contingente de tropas de peacekeeping. Pequim agora também é o segundo maior contribuinte para o orçamento de manutenção da paz da ONU, financiando 15\% do orçamento geral do programa (Best, 2020). Foi anfitrião da reunião anual do G-20, propôs novos acordos comerciais, criou um novo banco de desenvolvimento e ambiciona criar uma rede de infraestruturas mundiais que liguem a China ao Ocidente.

Tudo indica que o governo chinês decidiu escalar a sua política externa em relação aos EUA e a outros países, na tentativa de fazer com que a pandemia acelere a mudança do eixo diplomático entre as duas potências para o Oriente. Os diplomatas de Pequim veem o vírus como uma oportunidade de afirmar a liderança do regime entre países críticos do Ocidente (Lynch \& Gramer, 2020). Depois de ter, inicialmente, ocultado dados sobre a extensão do surto de coronavírus, manchando a credibilidade do regime, Pequim lançou uma agressiva ofensiva diplomática para 
projetar a imagem de potência benfeitora e generosa e defensor acérrimo da cooperação internacional (Yuan, 2020).

Ao que tudo indica, a OMS foi conivente com a negligência demonstrada pelo governo chinês na gestão da COVID-19. Em meados de janeiro, quando os chineses já sabiam que o coronavírus se transmitia entre humanos, a OMS veio a público dizer que não havia provas que confirmassem casos de transmissão entre humanos. Em vez de "nomear e envergonhar" a China, a OMS protelou uma atuação mais rigorosa até 20 de janeiro (a emergência sanitária foi declarada só a 30), elogiando as medidas extraordinárias que a China adotou para retardar a disseminação do surto e encorajando os Estados a continuar as relaçôes comerciais e não impedir as viagens para a China (Bollyky \& Huang, 2020).

Entretanto, a China lançou uma campanha de propaganda internacional em numerosas frentes com o propósito de moldar as perceçôes negativas sobre a sua atuação, demonstrando que podia salvar o mundo da pandemia gerada no seu próprio território. Em março, numa tentativa de reparar a sua reputação, a China afirmou ter contido, no essencial, a disseminação do coronavírus nas áreas mais atingidas e prometeu doar 20 milhóes de dólares à OMS para ajudar a melhorar os sistemas de saúde pública nos países pobres. A mensagem foi entregue pelo embaixador chinês à ONU numa altura em que a Europa e os Estados Unidos entravam na fase aguda da crise (Lynch, 2020). O foco da China na cooperação internacional difere bastante do da Casa Branca que usou principalmente a crise para culpar Pequim, direcionando a maior parte de suas energias para medidas internas de proteção contra o vírus, após ter, inicialmente, desvalorizado o problema, dando uma imagem de incompetência e descoordenação (Lynch \& Gramer, 2020).

Em finais de maio, Trump terminou o relacionamento entre os Estados Unidos e a OMS, que acusou de ser inapta na gestão da pandemia de COVID-19 e conivente com a China. Donald Trump alegou que a OMS não soube responder ao seu apelo para reformar a organização, depois de já ter ameaçado cortar o financiamento norte-americano (Euronews, 2020). Esta decisão foi criticada pela UE e pela China, que caracterizou como a atitude da administração como "egoísta e de fuga à responsabilidade”. Pequim instou a comunidade internacional a reforçar 
o multilateralismo e a aumentar o apoio político e financeiro à OMS (Abril, 2020): "Na verdade, já se tornou um hábito os Estados Unidos abandonarem os seus compromissos", afirmou o porta-voz do Ministério dos Negócios Estrangeiros chinês, acrescentando que esta ação "expõe uma vez mais a prática norte-americana do unilateralismo e da política de poder” (Abril, 2020).

O Partido Comunista Chinês mobilizou o seu aparato global de mensagens, que inclui mídia estatais e diplomatas chineses, para divulgar narrativas falsas sobre a origem do vírus. A diplomacia chinesa tornou-se particularmente agressiva com os seus "wolf warriors", diplomatas e funcionários encarregues da comunicação e informação. Os diplomatas e a agência de notícias ligada ao governo chinês subiram o tom de suas mensagens ao responder às críticas sobre a maneira como o país conduziu a pandemia. No final de abril, a agência de notícias Xinhua, próxima do Partido Comunista, divulgou um vídeo em que ridicularizava a forma como o governo americano lidou com a crise. A assertividade no tom do vídeo é o reflexo de uma China mais confiante de sua posição no mundo, muito distante da pendor discreto e terceiro-mundista do passado.

Além da frente das narrativas e da batalha pela informação, a China investiu também na "diplomacia sanitária”, enviando equipamento e médicos aos países do Sudeste Asiático, à Itália, Grécia e Sérvia. O Presidente da Sérvia agradeceu à China a ajuda no combate ao coronavírus, beijando, inclusive, a bandeira chinesa, e acusou a UE de se recusar a fornecer ao país equipamentos de proteção.

Alguns países provavelmente culparão a China por não tomar as medidas apropriadas nos estágios iniciais do contágio. No entanto, é provável que a China saia da crise com uma nova projeção do poder chinês. A China esforçou-se por reparar os danos à reputação causados pela sua resposta inicial e pela sua falta de transparência que permitiu que a doença se difundisse por todo o globo. O país também tentará capitalizar com o fracasso dos EUA em agir decisivamente no início da crise e se preparar para o que inevitavelmente viria depois que a doença se difundisse pelo mundo. Trump optou "por não usar a pandemia a seu favor na cena internacional. Poderia ter consolidado o domínio norte-americano, adotando uma posição mais generosa e respondendo aos apelos de apoio e à cooperação que vieram do mundo inteiro" (Babones, 2020, p. 60). 


\section{CONCLUSÃO}

Os analistas falam há muito sobre o fim de um sistema internacional liberal liderado pelos norte-americanos e a transição do poder para a Ásia. Isso está agora a acontecer, pois a pandemia provocada pela COVID-19 pode ser um ponto de viragem. A pandemia intensificou as disputas diplomáticas e a guerra discursiva entre EUA e China, mas não terá implicações mais críticas no curto prazo, como o agravamento da guerra comercial ou mesmo uma confrontação militar. Contudo, ela pode ter acelerado, de forma talvez irreversível, o confronto entres as grandes potências do século XXI. Enquanto isso, a China, em virtude de ser a primeira a emergir da crise, será a primeira a recuperar, estando já a dirigir todos os seus esforços para a retoma da economia chinesa.

É improvável que a pandemia impeça o reequilíbrio do poder económico global do Ocidente para o Oriente. A pandemia de coronavírus não dará início a uma ordem global inteiramente nova, mas acelerará as mudanças de maneiras importantes. Ele atuará como um acelerador das tendências geopolíticas existentes, em particular a crescente rivalidade entre os EUA e a China e a mudança no equilíbrio económico de poder do Ocidente para o Leste. Por fim, é provável que seja um catalisador de mudanças que atualmente são difíceis de antever, tanto no mundo desenvolvido quanto no mundo em desenvolvimento, do futuro papel dos EUA, ao crescente poder da China e ao papel da Rússia e de outras potências médias.

\section{BIBLIOGRAFIA}

Abril (2020). China pede mais apoio para a OMS e critica saída dos EUA, 2 de junho. Consultado em https:// www.abrilabril.pt/internacional/china-pede-mais-apoio-para-oms-e-critica-saida-dos-eua.

Allison, G.T. ( 2017). Destined for War: Can America and China Escape Thucydides's Trap? Boston \& Nova Iorque: Houghton Mifflin Harcourt.

Allison, G. (2020). “The New Spheres of Influence: Sharing the Globe With Other Great Powers.” Foreing Affairs.

Amitav, A. (2017). After Liberal Hegemony: The Advent of a Multiplex World Order. Ethics and International Affairs, 31(3), 271-285. https://doi.org/10.1017/S089267941700020X. 
Aníbal, S. (2017). Com a sombra de Trump a dominar, Davos vira-se para a China. Público, 16 de janeiro. Consultado em https://www.publico.pt/2017/01/16/economia/noticia/com-a-sombra-de-trump-a-dominar-davos-virase-para-a-china-1758506.

Babones, S. (2020). Bullied by Beijing, America's Closest Allies Regret Saying 'Yes' to China, 27 de junho. Consultado em https://foreignpolicy.com/2020/06/27/china-bullying-australia-new-zealand-canada-britain-trump/.

Babones, S. (2020). A América continuará a liderar o mundo. Le Courier Diplomatique 292, junho.

Behravesh, M. (2020), The Untold Story of How Iran Botched the Coronavirus Pandemic, Foreign Policy, 24 de março. Consultado em https://foreignpolicy.com/2020/03/24/how-iran-botched-coronavirus-pandemic-response/.

Best, L. (2020). What Motivates Chinese Peacekeeping?, CFR, 7 de janeiro. Consultado em https://www.cfr. org/blog/what-motivates-chinese-peacekeeping.

Bollyky, T. \& Huang, Y. (2020). The Multilateral Health System Failed to Stop the Coronavirus, Foreign Policy. 10 de março. Consultado em https://foreignpolicy.com/2020/03/10/the-multilateral-health-system-failed-to-stop-the-coronavirus/.

Crisóstomos, P. (2020). Vestager apoia travão a investidas da China em empresas estratégicas, Público, 13 de abril. Consultado em https://www.publico.pt/2020/04/13/economia/noticia/vestager-apoia-travaoinvestidas-china-empresas-estrategicas-1912108.

Cabral, F. S. (2020), China: um país, um sistema, RR, 25 de maio. Consultado em https://rr.sapo. pt/2020/05/25/francisco-sarsfield-cabral/china-um-pais-um-sistema/artigo/194072/.

Carr, V. E. H. (1983). The Twenty Years' Crisis, 1919-1939: An Introduction to the Study of International Relations. Londres: Macmillan.

Doyle, M. (1995). On the Democratic Peace. International Security, 19(4), 164-184.

Duncombe, C. \& Dunne, T. (2018). After Liberal World Order. International Affairs, 94(1), 25-42, https:// doi.org/10.1093/ia/iix234.

Dunne, T. \& Flockhart, T. (2011) eds, Liberal World Orders. Oxford: Oxford University Press.

Emmott, R. \& Koutantou. A. (2017). Greece Blocks EU Statement on China Human Rights at UN, Reuters, 18 June.

Euronews (2020). Trump "termina” relaçóes com OMS, 29 maio. Consultado em https://pt.euronews. com/2020/05/29/trump-termina-relacoes-com-oms.

European Commission (2019). European Commission and HR/VP Contribution to the European Council EU-China - A Strategic Outlook, 12 de março. Consultado em https:/lec.europa.eu/commission/publications/ eu-china-strategic-outlook-commission-contribution-european-council-21-22-march-2019 en. 
Fernandes, J. A. (2020). Balanço da COVID-19: China e América, “perdedores relativos”, Público, 30 de maio. Friedman, T. L (2020). Friedman: China, United States are heading for a divorce, The Mercury News, 24 de junho. Consultado em https://www.mercurynews.com/2020/06/24/friedman-china-united-states-are-heading-for-a-divorce/amp/.

Gilpin, G. (1981). War and Change in World Politics. Cambridge: Cambridge University Press.

Gomes, H. (2020) Hong Kong. Autonomia em vigor até 2047 pode não chegar sequer ao verão, Expresso, 30 de maio. Consultado em https://expresso.pt/internacional/2020-05-30-Hong-Kong.-Autonomia-em-vigorate-2047-pode-nao-chegar-sequer-ao-verao.

Gramer, R. \& Lynch, C. (2020). Trump Seeks to Halve U.S. Funding for World Health Organization as Coronavirus Rages, Foreign Policy, 10 de fevereiro. Consultado em https://foreignpolicy.com/2020/02/10/ trump-world-health-organization-funding-coronavirus-state-department-usaid-budget-cuts/.

Ikenberry, G. J. (2018). "Why the Liberal World Order Will Survive." Ethics and International Affairs, 32(1), 17-29. https://doi.org/10.1017/S0892679418000072.

Ikenberry, G. J. (2015). The Future of Liberal World Order.Japanese Journal of Political Science, 16(3), http:// doi.org/10.1017/S1468109915000122, 450-455.

India Today (2020). US foolishly fed the rise of China: Famed international relations expert John Mearsheimer, 20 de junho. Consultado em https://www.indiatoday.in/india/story/us-foolishly-fed-rise-of-china-international-relations-expert-john-mearsheimer-1691051-2020-06-20.

Jørgensen, K. E. (2014). "After Hegemony in International Relations, or, the Persistent Myth of American Disciplinary Hegemony.” ERIS, 1-2014, 57-64. https://doi.org/10.3224/eris.v1i1.19605.

Kahler, M. (2016). Conservative Globalizers: Reconsidering the Rise of the Rest. World Politics Review, 2 de fevereiro. Consultado em_https://www.worldpoliticsreview.com/articles/17840/conservative-globalizers-reconsidering-the-rise-of-the-rest.

Kakissis, J (2018). Chinese Firms Now Hold Stakes In Over A Dozen European Ports, NPR, 8 de outubro. Consultado em https://www.npr.org/2018/10/09/642587456/chinese-firms-now-hold-stakes-in-over-adozen-european-ports.

Keohane, R. O. (1984). After hegemony: cooperation and discord in the world political economy. Princeton, NJ: Princeton University Press.

Kothari, M. (2018). China’s Trojan Horse Human Rights Resolution, The Diplomat, 22 de março. Consultado em https://thediplomat.com/2018/03/chinas-trojan-horse-human-rights-resolution/.

Krauthammer, C. (1990-1991). The Unipolar Moment”, Foreign Affairs - America and the World 1990/91, $70(1), 23-33$. 
Li Keqiang (2017), China Premier Li Keqiang: 'Economic Openness Serves Everyone Better', Bloomberg Businessweek, 26 de janeiro. Consultado em https://www.bloomberg.com/news/articles/2017-01-26/china-premier-li-keqiang-economic-openness-serves-everyone-better.

Lynch, C. \& Gramer, R. (2020). U.S. and China Turn Coronavirus Into a Geopolitical Football, Foreign Policy, 11 de março.. Consultado em https://foreignpolicy.com/2020/03/11/coronavirus-geopolitics-china-united-states-trump-administration-competing-global-health-response/.

Lynch, C. (2020). China Goes on Diplomatic Offensive Over Coronavirus Response, Foreign Policy, 6 de março. Consultado em https://foreignpolicy.com/2020/03/06/china-coronavirus-response-diplomatic-offensive-united-nations-document/.

Mearsheimer, J. J. (2019). Bound to Fail: The Rise and Fall of the Liberal International Order. International Security, 43(4), 7-50. https://doi.org/10.1162/ISEC_a 00342.

Maull, H. W. (2019). The Once and Future Liberal Order. Survival, 61(2), 7-32. https://doi.org/10.1080/00 $\underline{396338.2019 .1589076 .}$

Mitchell, R. (2018). Was the UN Human Rights Council Wrong to Back China's "Shared Future” Resolution?, EJIL: Talk!, 10 de abril. Consultado em https://www.ejiltalk.org/was-the-un-human-rights-council-wrong-to-back-chinas-shared-future-resolution/.

Moore, G. J. (2017). Avoiding a Thucydides Trap in Sino-American Relations (...and 7 Reasons Why That Might Be Difficult). Asian Security, 13(2), 98-115. https://doi.org/10.1080/14799855.2017.1286162.

Nuruzzaman, M. (2020). "Why BRICS Is No Threat to the Post-War Liberal World Order. International Studies, 57(1), 51-66. https://doi.org/10.1177/0020881719884449.

Nye, J. S. (2017). Will the Liberal Order Survive?: The History of an Idea. Foreign Affairs, janeiro/fevereiro.

Peel, M.; Warrell, H.; Solomon E. \& Katrina, K. (2020). Nato chief urges nations to stand up to 'bullying' as China power rises, Financial Times, 8 de junho. Consultado em https://www.ft.com/content/e05f45fb-49a$\underline{8-4798 \text {-bcfc- } 1052080 \text { e } 45 \mathrm{~cd} .}$

Ruggie, J.G. (1983). International regimes: transactions and change; embedded liberalism in the postwar economic order. In Krasner, S. (Ed.), International regimes. (pp. 195-232). Ithaca: Cornell University Press.

Ruggie, J. G. (1982). International regimes, transactions, and change: embedded liberalism in the postwar economic order, International Organization, 36(2), 379-415.

Sitaraman, S. (2020). China's Salami Slicing Tactics and the Latest India-China Border Standoff, DKI APCSS. Consultado em https://apcss.org/nexus_articles/chinas-salami-slicing-tactics-and-the-latest-indiachina-border-standoff/.

Stephen, M. D. \& Skidmore, D. (2019). The AIIB in the Liberal International Order. Chinese Journal of International Politics, 12(1), 61-91. https://doi.org/10.1093/cjip/poy021. 
Strange, S. (1988). States and Markets: An Introduction to International Political Economy. Londres: Pinter Publishers.

Strange, S. (1987). The Persistent Myth of Lost Hegemony, International Organization, 41(4), 551-574.

The Economist Intelligence Unit (2020). Geopolitics after COVID-19: is the pandemic a turning point? Consultado em https://country.eiu.com/article.aspx?articleid=1339299717\&Country=Albania\&topic=Politics\&subtopic=Forecast\&subsubtopic=International+relations.

Walt, S.M. (2018). The World Wants You to Think Like a Realist. Foreign Policy. Wong, E.; Rosenberg,

M. \& Barnes, J. E. (2020). Chinese Agents Helped Spread Messages That Sowed Virus Panic in U.S., Officials Say, The NYT, 22 de abril. Consultado em https://www.nytimes.com/2020/04/22/us/politics/coronavirus-china-disinformation.html.

Yuan, S. (2020). State media lauds China as global leader in fight against disease in bid to defuse criticism it allowed virus to spread, Al Jazeera, 26 de março. https://www.aljazeera.com/news/2020/03/china-coronavirus-propaganda-push-ties-worsen-200325085419818.html?fbclid=IwAR2PUopvjwsL7UMkfvVMjX65j8PPu1rIic9NsjazwvtzmL2voNviT5Ii7Dc. 